\title{
Ten years after: capital flows and the global monetary order*
}

\author{
Thomas Reininger, Helene Schuberth** and Michael Wögerer \\ Oesterreichische Nationalbank (OeNB), Vienna, Austria
}

\begin{abstract}
Cross-border bank flows, which had surged in the run-up to the global financial crisis (GFC), shrank significantly after the GFC. According to our findings, this development did not point to financial deglobalization, as was widely expected. Instead, it reflected a cross-border deleveraging of (core) European banks seeking to restore their capital positions. The GFC triggered regulatory reforms that were remarkable, especially with regard to the banking system. Nevertheless, the opportunity to fundamentally overhaul the regulatory regime in general and the global monetary order in particular was not seized. While regulatory reform has progressed incrementally during the last decade, the partial retreat of the USA from multilateralism has brought this issue back onto the table.
\end{abstract}

Keywords: global financial system, capital flow volatility, current-account imbalances, shadow banking

JEL codes: E42, E52, E66, F33, G01

\section{INTRODUCTION}

Back in fall 2008, hopes were high that the traumatic moments experienced would trigger a fundamental overhaul of the global financial system. As a result, finance would become more resilient and serve society, and the primacy of politics over global financial markets would be reinstated. What did the expectations look like specifically? First, after the onset of the global financial crisis (GFC), public-sector debt was widely expected to increase amid a deleveraging of the private sector. Second, since the GFC was not a run on banks, as in the 1930s, but a titanic run on the shadow banking system, the obvious response would have been to regulate shadow banks and shadow bank activities. Third, the end of hyperglobalization in finance, that is, the retrenchment of cross-border capital flows, was widely anticipated. It was not net capital flows - the mirror image of the current-account balance - that had been rising immensely up to the GFC but previously neglected gross capital flows (Borio/Disyatat 2015). Fourth, gross capital flows were intermediated by a handful of large and complex financial institutions (including banks) in the USA and in Europe. Before the GFC, these institutions rapidly expanded their balance sheets and dominated the global financial markets for debt and equity securities, syndicated loans, securitizations, structured financial products and over-the-counter (OTC) derivatives. After the GFC, the breakup and downsizing of banks considered too big to fail was widely anticipated.

Fifth and finally, the US dollar had played a central role in underpinning the upsurge of global credit flows of the banking as well as the shadow banking system, which ultimately contributed to the financial meltdown in 2008. Many predicted that the US dollar would lose its status as the world's leading currency. Hence, a strong move of the tectonic

* The views expressed do not necessarily represent the views of the OeNB or the ESCB.

** Corresponding author: Email: Helene.schuberth@oenb.at. 
plates toward some kind of more or less fractious multipolarity was envisaged; some even called for a New Bretton Woods, where the US dollar would be replaced by a global currency, potentially triggered by the biggest desired overhaul of the world's monetary system since 1944. Nothing of the latter has become a reality. The failure to act in those days appears in a different light today. Had policy-makers anticipated the USA's fundamental change in foreign economic policy, which seems to be incompatible with a strong role of the US dollar in the long run, they might have felt more inclined to undertake reforms.

The paper is structured as follows. First, the above-mentioned expectations arising in fall 2008 are contrasted with the outcomes (Section 2). While there have been pockets of reform that deserve merit, in particular with regard to the increased resilience of the banking system, many of the expectations were not met. In particular, the opportunity to fundamentally reform the global monetary order was not seized. Section 3 discusses the main characteristics and deficiencies of the prevailing monetary order. This is followed (in Section 4) by a brief debate of the reform proposals being discussed. Section 5 concludes.

\section{OUTCOMES VERSUS EXPECTATIONS}

In 2009, the G20 launched regulatory reforms, coordinated by the Financial Stability Board (FSB), that focused on four main pillars: (i) making financial institutions more resilient; (ii) eliminating the too-big-to-fail phenomenon; (iii) regulating OTC derivatives; and (iv) introducing bank resolution tools. The reforms - not least Basel III, enhanced bank resolution regimes, the central clearing of all standardized derivatives contracts and the implementation of macroprudential policy tools - have substantially strengthened financial institutions, in particular banks. This progress notwithstanding, vulnerabilities of the global financial system remain elevated (IMF 2018c; ECB 2018b). Further, when we compare the outcomes with the expectations immediately after the GFC, there seems to be a wide consensus that the outcomes fell short of some of the expectations.

\subsection{Leverage in the global economy}

In contrast to the widely expected deleveraging of the private sector and leveraging-up of the public sector, global gross debt continues to hit new record highs. According to the IMF's Fiscal Monitor (IMF 2018a), global total debt, comprising the government, households and non-financial firms, came in at a record \$164 trillion in 2016, amounting to 225 percent of the world economy's gross domestic product (GDP); that level of debt was 12 percentage points higher than the last high seen in 2009 immediately after the onset of the GFC. Not only public but also private debt has surged over the past decade. Of the $\$ 164$ trillion, 63 percent is non-financial private-sector debt, and 37 percent is public-sector debt. Advanced economies account for most of the global non-financial private-sector debt (around 160 percent of their own GDP). While all country groups experienced increases in total private debt, emerging market economies are in the lead by a wide margin; having doubled in a decade, their private-debt ratios reached 120 percent of their own GDP by 2016 . China alone contributed almost three-quarters of the increase in global private debt since 2007.

\subsection{Shadow banks and shadow bank activities}

The post-crisis regulatory reform agenda has made the major banks more resilient, primarily thanks to the implementation of the Basel III package. Given the dominance of 
entity-based over activity-based regulation, risks have partly migrated to the shadow banking system, which - based on a narrow measure ${ }^{1}$ for 29 jurisdictions comprising 80 percent of world GDP - grew from \$28 trillion in 2010 to \$45 trillion in 2016 (FSB 2018). When other financial intermediaries (OFIs) are used as a broader measure, ${ }^{2}$ the balance sheet of the shadow bank entities increased from $\$ 60$ trillion to $\$ 99$ trillion from 2010 to 2016, growing on average by 9 percent annually. This reflects a strong increase in China's shadow banking system to $\$ 9.6$ trillion (from rather low levels), an increase in the USA to $\$ 27.1$ trillion and a steady increase in the euro area to $\$ 32.2$ trillion. At a 30 percent share in global OFI assets, the euro area has the largest OFI sector. The rapid growth of the shadow banking system may not only be attributable to the dominance of entity-based regulation focusing on banks. It may also partly reflect the strong demand of large global corporations for non-bank intermediation. In the USA, cash holdings, having grown significantly in the aftermath of the GFC, are concentrated among a handful of firms (S\&P 2017). They are invested in higheryielding financial instruments issued by shadow banks instead of being deposited with banks.

The strong rise in the size of the balance sheets of shadow banks and shadow activities, such as repurchase agreements, over the last decade poses risks in particular from liquidity and maturity transformation. This may cause spillovers to the wider financial system as the interconnectedness between OFI subsectors and the rest of the world is high, especially for jurisdictions which act as hubs for international capital flows. Such risks may also contribute to the amplification of credit cycles across the financial system. Post-crisis regulatory reforms have only partially progressed in addressing those risks, with significant reforms related to money market funds (FSB 2018; IMF 2018c) accomplished only recently.

\subsection{End of hyperglobalization in finance?}

Gross capital in- and outflows unprecedently surged in the run-up to the GFC followed by a strong retrenchment (see Figure 1). World gross capital inflows have since moderated to less than half of their pre-crisis levels. This is occasionally used as evidence for an overall financial deglobalization since 2008. While global trade has recovered to its pre-crisis levels, capital account globalization has allegedly reversed to levels seen in the early 1990s. But numerous aspects caution us to portray these extraordinary events as indicative of a process of overall financial deglobalization.

Advanced Europe stands out as the region that has received by far the largest gross inand outflows relative to global GDP since the mid 1990s - this is probably one of the most extraordinary episodes in history of financial globalization. This surge is particularly visible when gross capital flows are shown as a percentage of own GDP (see Figure 2).

1. The narrow measure of shadow banking includes non-bank financial entity types that authorities have assessed as being involved in credit intermediation that may pose financial stability risks, based on the FSB's methodology and classification guidance. In 2016 this narrow measure accounted for 13 percent of total financial assets.

2. As a conservative proxy for a broader measure of shadow banking, 'other financial intermediaries' are used, which are all financial institutions that are not central banks, banks, insurance corporations, pension funds, or public financial institutions. In 2016 this broader measure accounted for 30 percent of total financial assets. OFIs comprise investment funds, money market funds, hedge funds, real estate funds, etc. 

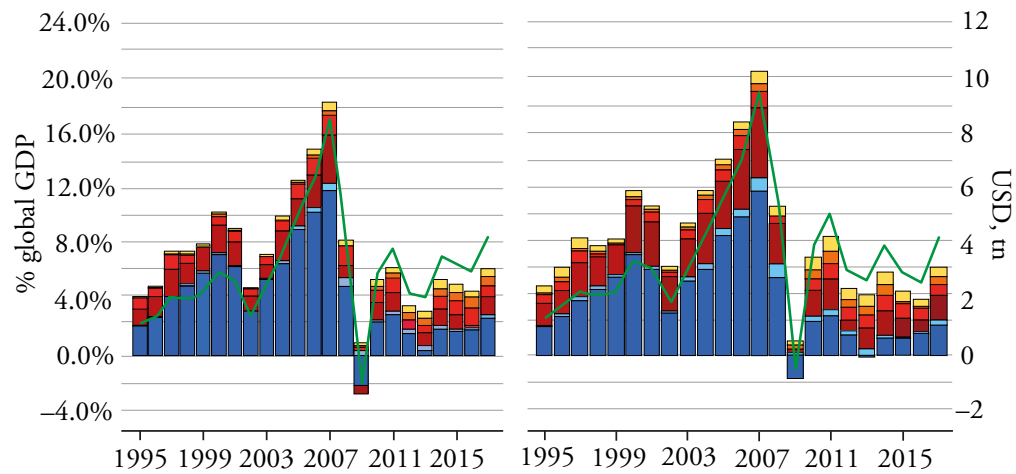

$\square$ Other EM $\square$ Advanced Non-Europe

$\square$ CESEE

_ Global (RHS scale)

$\square$ China $\square$ US

$\square$ Advanced Europe

Note: Gross capital outflows (LHS), gross capital inflows (RHS).

Source: BIS; authors' calculations.

Figure 1 Gross capital flows by country group
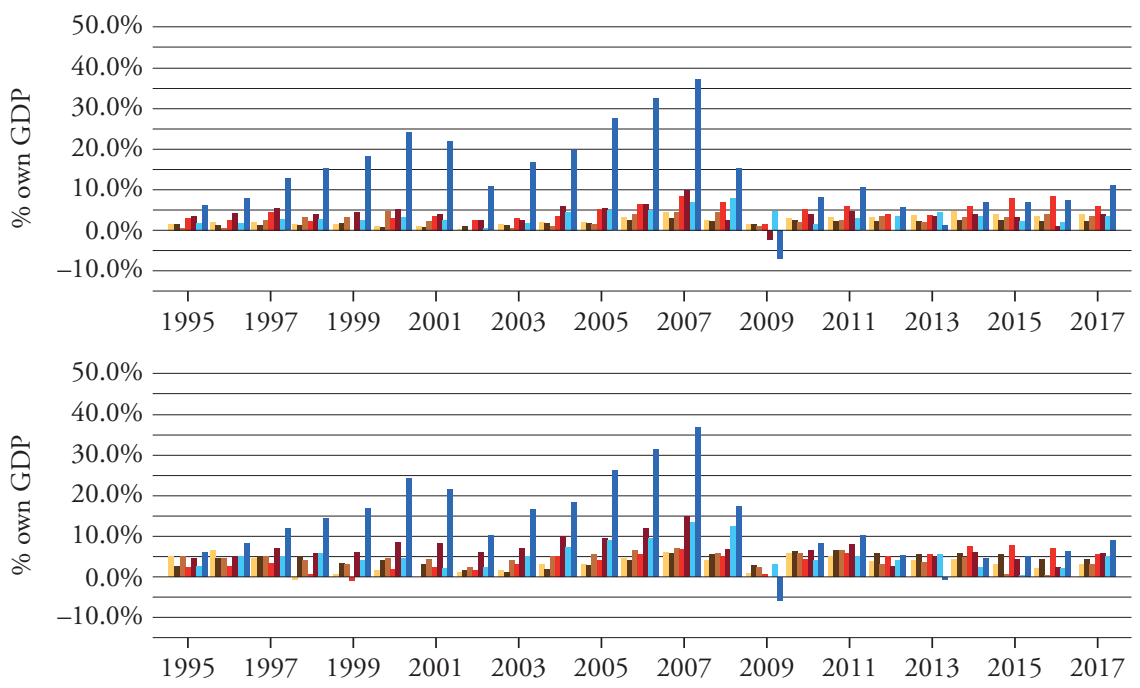

Asia (excluding China)

Latin America

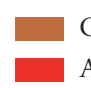

China

Advanced Non Europe
US

CESEE

Note: Upper graph shows outflows, lower graph shows inflows.

Source: BIS; authors' calculations.

Figure 2 Gross capital flows by country group (compared to own GDP) 
In 2007, Advanced Europe received around 40 percent of gross capital in- and outflows expressed as a percentage of own GDP (including intra-European capital flows). The slowdown thereafter was momentous for Advanced Europe but less harsh in the other regions of the world. Central, Eastern and Southeastern Europe (CESEE) also experienced a pronounced capital flow cycle (Eller et al. 2016), where in the years following the 2004 enlargement round of the European Union (EU) gross capital inflows reached up to 15 percent of own GDP, which was later followed by a sharp slowdown. During the 2008-2009 crisis, the CESEE region as a whole saw larger output declines than any other region in the world (Berglöf et al. 2010).

Interestingly, the retrenchment following the crisis fundamentally changed the composition of capital flow categories. Disregarding cross-country heterogeneity, the slowdown was driven by bank flows (other investment, see Figure 3). Bank flows that used to account for the largest share of total gross capital in- and outflows before the GFC declined substantially, which mainly reflected large global banks' deleveraging and restraint in cross-border operations in response to regulatory reform. In contrast, FDI flows, having slightly trailed bank flows in the pre-crisis period, remained rather resilient and contracted much less than bank flows.

A closer inspection of the geography of bank flows reveals that banks in Europe drove the decline of global cross-border lending (see Figure 4, right-hand scale), while still holding around half of global cross-border claims (see Figure 4, left-hand scale). Note that around half of this share are still cross-border claims against other European countries. The decline of European banks' foreign claims can first be explained by their endeavors to restore their capital position, in part through reducing total assets, including cross-border claims (McCauley et al. 2019). Second, the decline reflects the unwinding of claims of banks in Core Europe against the euro area periphery. As a sign of fragmentation, this shows that major euro area reforms have yet to be accomplished.

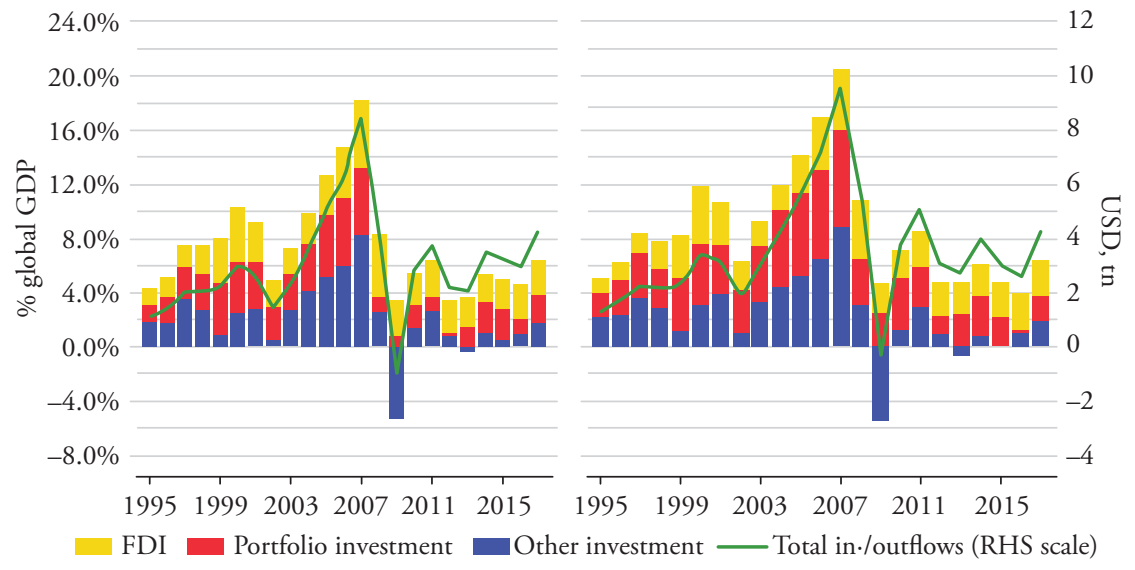

Note: Gross capital outflows (LHS), gross capital inflows (RHS).

Source: BIS; authors' calculations.

Figure 3 Gross capital flows by capital flow category 

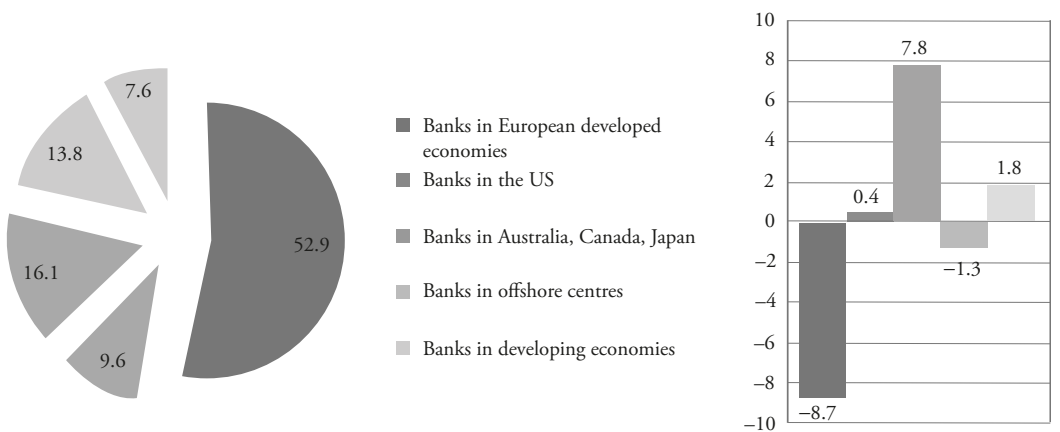

Note: Percentage of total cross-border claims of all banks reporting to BIS, at end 2017 (LHS); 2007 to 2017 percentage-point change of the share in total cross-border claims of all banks reporting to BIS at 2017 exchange rates (RHS).

Source: Own estimations, based on data provided by BIS.

Figure 4 Cross-border claims of banks by region of bank location

The ultimate outcome of the crisis was thus not the end of hyperglobalization in finance, but a partial adjustment of the particularly strong position of banks in Core Europe that characterized the 1990s and early years of this century.

\subsection{End of too-big-to-fail?}

Today banks, including the large ones, are much more resilient than they were a decade ago, they are substantially better capitalized, and their funding patterns are much more sustainable. But the size of large banks, which is - on top of interconnectedness - an important characteristic of a too-big-to-fail bank, has on average not shrunk. When we compare the 20 largest banks in terms of the size of the balance sheet, we see that China's largest banks, having overtaken euro area banks, have become the world's largest banks by assets. $^{3}$ A simple concentration measure - the size of the balance sheets of the five biggest banks relative to domestic GDP - reveals that, between 2007 and 2017, market concentration strongly increased in China, declined somewhat in the USA and weakened more significantly in the EU - with strong cross-country heterogeneity (see also ECB 2017). Regulatory reform, in particular Basel III, together with weaker economic activity, had some impact on the deleveraging of large European banks.

But doubts had already been cast on 'whether the largest and most trading intensive banks in Europe can be rapidly resolved in the midst of a systemic crisis'. ${ }^{4}$ A Banking Structural Reform proposal, released by the European Commission in 2014, that stipulated, above all, a prohibition of proprietary trading and investment in hedge funds as well as a potential separation of trading activities, had to be withdrawn in 2017 for lack of political support.

However, it has to be acknowledged that under the auspices of the Financial Stability Board important internationally agreed steps towards enhanced resolvability of global systemically important banks (G-SIBs) were taken. G-SIBs have to meet minimum

3. Data source: SNL Financial.

4. Erkki Liikanen, ECON hearing, European Parliament, 2 December 2014. 
total loss-absorbing capacity (TLAC) requirements from 2019 onwards, or from 2025 onwards if they are headquartered in an emerging market economy (FSB 2015). This should increase the probability that the materialization of idiosyncratic risks of very large banks could be addressed by applying bail-in tools. Nevertheless, one may question whether the bail-in instrument works satisfactorily in a systemic crisis.

\subsection{New global monetary order}

In the run-up to the G20 meeting on 15 November 2008, many public sector officials ${ }^{5}$ and academics ${ }^{6}$ hoped that the GFC would trigger an ambitious rebuilding of the international financial system similar to what was achieved at the 1944 Bretton Woods conference which established the post-war international financial order. In March 2009, Governor Zhou from the People's Bank of China launched his own call for a new Bretton Woods along the lines of Keynes's proposals (Zhou 2009). He challenged the US dollar's privileged status as the world's global reserve currency and advanced the idea of a super sovereign reserve currency, a role that he argued could be played by the IMF's special drawing rights (SDRs). There would be a true anchor of stability that was not at the mercy of a single super-power. The US dollar apparently played a decisive role in reinforcing the strong leverage of the global financial system; it was used for structuring complex derivatives and for denominating debt to foreign borrowers. The GFC thus invigorated an older debate about the structural deficiencies of the International Monetary System (IMS) with the US dollar as the world's dominant currency (see Section 3). As the US dollar is widely used outside the USA, including as a reserve currency by non-US savers, as an invoicing currency by non-US exporters and importers, and as a funding currency by a wide array of non-US borrowers, changes in its value may have significant consequences for the global economy far beyond the traditional direct effects on external trade.

Before the GFC, the large current-account deficit of the USA of up to 6 percent of GDP (in 2006) and an abrupt depreciation of the value of the US dollar were seen as the dominant risk factors in the global economy (see for example IMF 2007). But far from weakening the value of the US dollar, the GFC in fact strengthened it. Between July 2008 and March 2009, the US dollar sharply appreciated against major currencies, reflecting a flight to safety, an increased need for US dollar liquidity and the unwinding of carry trade positions (Fratzscher 2009). From 2010 to early 2019, the US dollar appreciated by around 30 percent in nominal effective terms, mainly because earlier monetary policy normalization and positive growth differentials favored capital inflows into the USA.

Based on various metrics, the US dollar sustained its status as the world's leading currency (see Figure 5). Even though the US share in world GDP at purchasing-power parity (PPP) declined from 18 percent to 15 percent from 2007 to 2017, half of the

5. Nicolas Sarkozy and Gordon Brown were pursuing plans for a Bretton Woods II conference. Henry Paulson's call for Bretton Woods II reflected his concern about the huge current-account deficits that were building up prior to the crisis. This call was reiterated by Sarkozy in Davos in 2010 when, remarkably, he commented that he believed the US dollar should no longer be the primary reserve currency in the global economy. Gordon Brown, as noted by Adam Tooze (2018), was determined to avoid a disaster like that of the London 1933 World Economic Conference that symbolized the descent into disintegration and economic nationalism.

6. Joseph Stiglitz chaired a United Nations commission that issued a report saying that there needed to be 'a new global reserve system' that did not rely on the US dollar as the single major currency (UN 2009). 


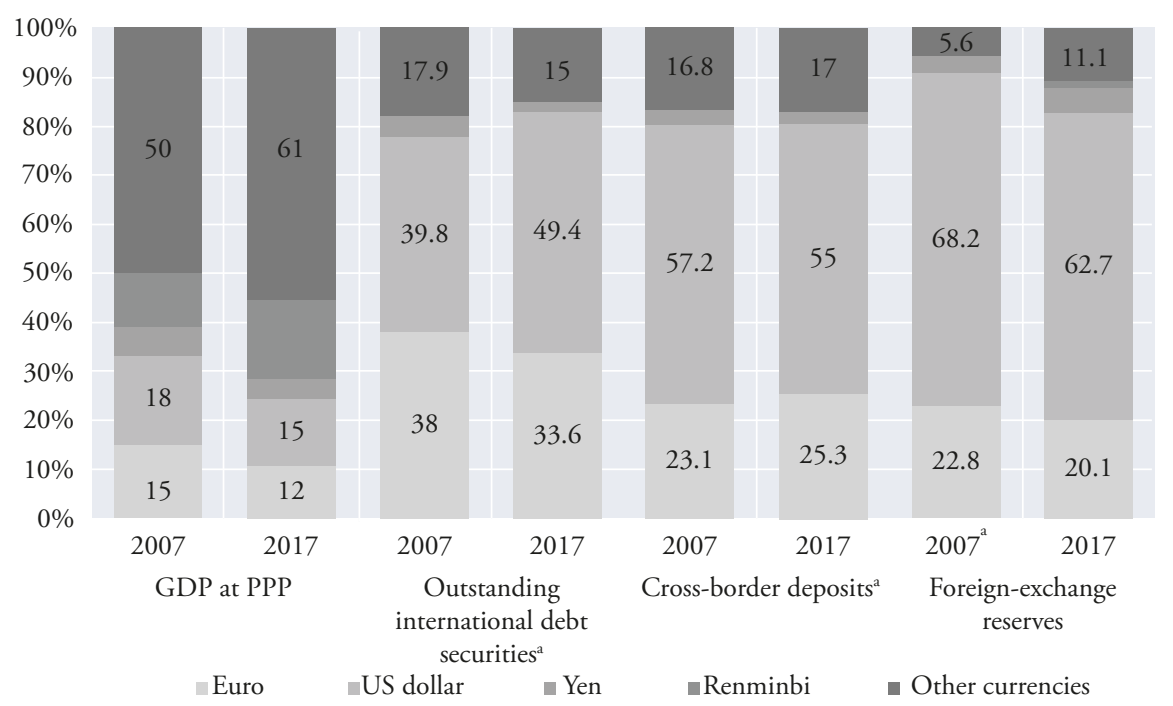

Notes: 2007 and 2017 values in percentage world volume. a. indicates that no data on renminbi are available.

Source: ECB.

Figure 5 The international role of the US dollar

outstanding international debt securities worldwide are denominated in the US dollar, up from 40 percent in 2007. This reflects, above all, dynamic borrowing via emerging market issues amid historically low levels of interest rates (Avdjiev et al. 2018a). The US dollar remained the most commonly used currency in global payments in 2017 (accounting for about 40 percent of the payments in question), followed by the euro (36 percent) (ECB 2018a). The US dollar is still the most important reserve currency by far, although its share has declined from 68 percent to 63 percent in the last decade, which is due to a strong decline since 2016 (valuation effects). In spite of the internationalization strategy for the renminbi, the share of the Chinese currency stood at only about 1 percent in 2017, which reflects the 2015 reintroduction of capital controls that have been partially lifted since then.

Since the late 2000s, the GDP-weighted share of the countries that linked their currencies to the US dollar by a currency board, had a fixed exchange rate, or used the US dollar as a reference in order to limit currency volatility remained stable at 50 percent. This share increases to 70 percent when the unweighted share of countries is considered (Ilzetzki et al. 2019).

\section{CURRENT GLOBAL MONETARY ORDER: STRUCTURAL DEFICIENCIES}

\subsection{Excessive accumulation of foreign-exchange reserves}

After the breakdown of the Bretton Woods regime many believed that countries would reduce their demand for foreign-exchange reserves. Yet the opposite has been the case, 


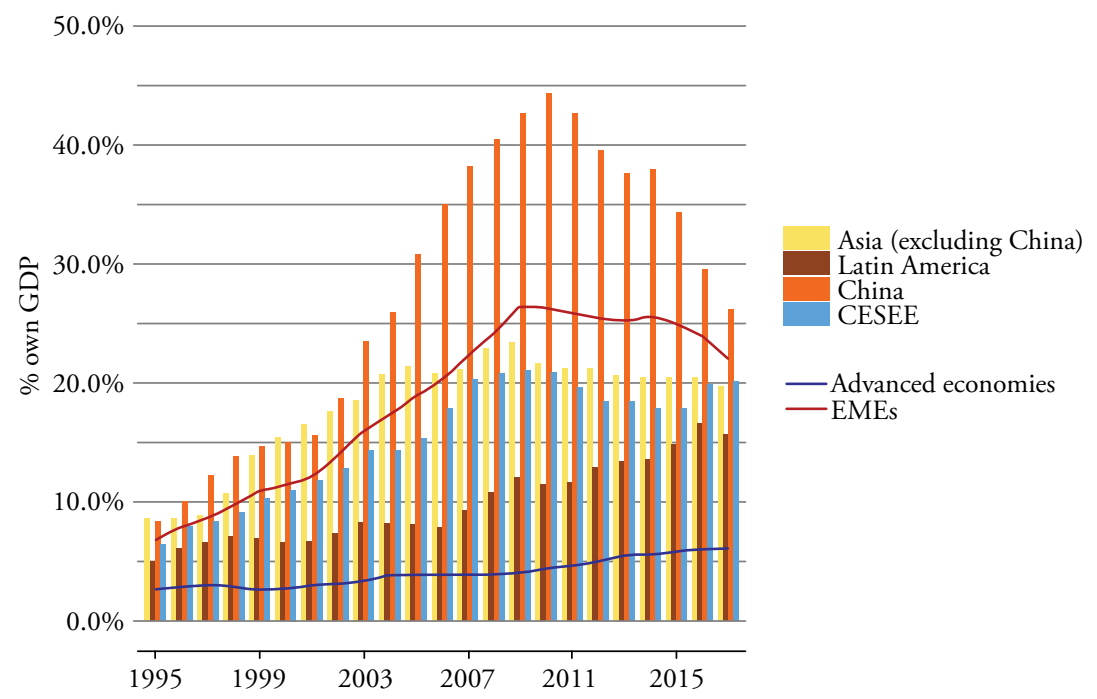

Source: BIS; own calculations.

Figure 6 Excessive accumulation of foreign-exchange reserves

with the overall stock in foreign-exchange reserves having increased. A particularly strong surge has been evident since the Asian financial crisis in the late 1990s (see Figure 6). Reserves relative to own GDP held by emerging and developing countries rose from about 7 percent in 1993 to roughly 25 percent in 2007 and declined to slightly above 20 percent in 2017, mainly reflecting the decumulation of foreign-exchange reserves of the People's Bank of China. They increased from 3 percent to 5 percent in advanced economies, which have been able to borrow more easily on world capital markets and have therefore had less need for international reserves. Three factors may explain the unprecedented surge in reserves in poorer countries. First, emerging market economies and developing countries have been subject to fluctuations in commodity prices, abrupt movements in world interest rates and pro-cyclicality of capital flows. Many of them therefore started to accumulate large amounts of reserves as a self-insurance mechanism. Second, a less significant factor is the mercantilist motive. The respective countries intend to maintain a competitive exchange rate vis-à-vis the US dollar, which in turn creates strong deflationary forces in the US economy (Bibow 2010). Third, the rise in reserves may be related to strategies meant to help cope with the impossible trinity (Ilzetzki et al. 2019). Countries that reduce their reliance on capital controls may wish to stabilize the exchange rate - by sterilized interventions - and keep control over the interest rate. Overall, it is noteworthy that the evolution of integrated world capital markets following capital account liberalization has made the need for key currency liquidity support much more pressing today than was the case during the Bretton Woods era (Obstfeld 2013).

The implications of large-scale reserve accumulation can be serious. For the accumulating country, opportunity costs in terms of foregone consumption and investment are involved. If reserve accumulation is associated with current-account surpluses, it may have a deflationary impact in case the deficit countries are no longer willing to incur further current-account deficits. 


\subsection{Asymmetry in the adjustment mechanisms between borrowing and lending countries}

One may argue that an adjustment mechanism orchestrated by a public authority to sanction lending countries may be an important complement to the prevailing market mechanism that sanctions deficit countries only. A large middle- or higher-income country may give rise to negative externalities in the form of exporting unemployment and/or financial instability if it follows a mercantilist strategy and has large currentaccount surpluses over a longer period of time, in particular if the surplus is not fundamentally justified. At the same time, current-account imbalances that are too often a mirror image of internal imbalances are inextricably linked to the prevailing global monetary order, since, for most economies, current-account surpluses are the main non-debt-creating source of global liquidity (see also Subsection 3.4).

As noted by Bibow (2010), the current monetary order and the associated global imbalances were often portrayed as exhibiting a symbiotic and hence sustainable interplay between the USA, which provides the key reserve currency in terms of safe and highly liquid assets, and other countries, which are - to a large extent - surplus economies (Dooley et al. 2003). While the latter wish to spur growth by selling products to the large US market, the USA benefits from providing the key reserve currency and becoming a 'bold world venture capitalist,' which in turn allows the USA to run larger account deficits without broadly worsening its external position (Gourinchas/Rey 2007). In non-crisis times, the USA enjoys a sizeable excess return of gross assets over gross liabilities ('exorbitant privilege') of about 2 percent annually (Gourinchas et al. 2010): It borrows at low costs by selling highly liquid, low-risk Treasury securities and purchases high-yielding risky assets (Dooley et al. 2003). Until the GFC, rising private-sector indebtedness as well as the flexible macroeconomic adjustment in the USA that was supported by the dual mandate of the Federal Reserve System sustained the world's 'consumer and borrower of last resort function' of the key reserve issuer.

When the crisis hit, the 'exorbitant privilege' eventually became an 'exorbitant duty' reflected in a large fall in the US net foreign asset position (Gourinchas et al. 2017). The alleged symbiosis of the key currency issuer and the rest of the world proved to be untenable because external imbalances were the mirror image of unsustainable internal imbalances, above all debt-financed consumer spending by the household sector (Bibow 2010). The external rebalancing process in the USA - the current-account deficit declined from 6 percent in 2008 to around 2 percent ten years later - was less painful, because the government sector offset the deflationary forces of private-sector deleveraging. It was much more tedious in European countries that had previously had current-account deficits and where contractionary deleveraging was a common policy response (Gächter et al. 2015). In the post-GFC process of external rebalancing, the euro area took over the role of China as the major (surplus) counterpart of the US current-account deficit. The euro area turned its current-account deficit of -1.5 percent (2008) into a surplus of up to 3 percent (2018), which mostly reflects asymmetric rebalancing within the euro area. By contrast, China rebalanced away from exports, lowering its current-account surplus from 9 percent in 2008 to 1.8 percent in 2011 and 1.4 percent in 2018 .

\subsection{Capital flow volatility, sudden stops and the global financial cycle}

One key lesson of the GFC is that global imbalances are not synonymous with currentaccount imbalances, as the build-up of large gross capital in- and outflow positions can go hand in hand with a balanced current account (Borio/Disyatat 2015), as painfully 
experienced in the euro area where large external financial positions were building up that were not visible in the (balanced) current account.

The opening-up of the capital account starting in the 1980s sharply increased financial integration and systemic interconnectedness as well as boom-bust cycles in capital flows that tend to be more significant than domestic credit cycles (Lane/McQuade 2014). Extensive capital inflows tend to fuel the build-up of macro-financial imbalances, such as excessive credit (including foreign-exchange-denominated lending), rising currency mismatches, surging property and asset prices, and inflationary or currency appreciation pressures. Sudden stops and reversals of capital flows usually trigger sharp economic downturns with a lasting impact and leave the banking system with rising non-performing loans that act as an additional drag on lending.

Very often volatile cross-border capital flows represent a challenge to cyclical conditions in emerging and advanced economies alike. Post-crisis examples are the surge of capital flows to some emerging markets in the aftermath of monetary accommodation in the advanced economies following the GFC and the withdrawal of cross-border capital from some emerging economies after the Federal Reserve System's tapering announcement in May 2013 (see IMF 2016). Recently, monetary tightening in the USA has led to a deterioration of financial conditions of emerging markets that are highly indebted in US dollars. Contrary to the standard trade channel, a depreciation of the emerging market's currency triggers a decline in real investment via the financial channel that operates via valuation changes, balance-sheet adjustments and shifts in risk-taking (Avdjiev et al. 2018b). As emerging markets become ever more linked to the US dollar, the financial channel has gained in importance, with the US dollar coming to represent a global risk factor.

The connection between the surge of gross capital inflows and financial boom-bust cycles surrounding the GFC has revived a long-standing debate about the determinants of global capital flows. In particular, the question of whether pull or push factors are driving capital flows has increasingly attracted attention in the wake of the taper tantrum of 2013 and the subsequently observed large declines in currency values and domestic asset prices in most of the emerging countries. According to the pertinent literature, push factors typically refer to fluctuations in global risk aversion or monetary policy in advanced economies that drive capital flows into emerging markets, while pull factors reflect domestic fundamental economic conditions that pull capital into a country. Various attempts have been made to empirically assess the relative importance of global push versus domestic pull factors. In general, the majority of the contributions provide evidence for the predominance of common push factors over domestic economic forces. Rey (2015) and Miranda-Agrippino/Rey (2018) notably maintain that a single global financial factor driven primarily by shifts in international investors' risk aversion as well as monetary policy in center countries account for much of the volatility of capital flows. Eller et al. (2018) substantiate the view that global financial factors explain a major share of capital flow volatility. Bruno/Shin (2015) stress the crucial role of cross-border flows via global banks that transmit financial conditions from the center across the globe.

If push factors are the dominant drivers of capital flows - and negative cross-border spillovers prevail - some have argued that macroprudential policies may or should also include capital flow management measures to shelter the economies from global shocks. A related implication was notably suggested by Rey (2015) and Miranda-Agrippino/Rey (2018): Given the sensitivity of non-center countries to a global financial cycle which can lead to excessive credit growth that is not aligned with a country's economic conditions, the choice of the exchange-rate regime does not matter. Mundell's 'trilemma' may have 
morphed into a 'dilemma' where autonomous monetary policy is no longer effective, irrespective of the exchange-rate regime. Restricting the capital account would be the only way to retain autonomy in monetary policy.

\subsection{The Triffin dilemma and its modern version: the need for safe assets}

Another concern is the imbalance between the growing demand for US reserve assets given the share of emerging and developing countries in world GDP - and the limited supply of reserve assets. This concern, which is related to the above-mentioned issue of excessive accumulation of foreign-exchange reserves, has much broader implications.

This imbalance is often referred to as a modern version of the Triffin dilemma, ${ }^{7}$ which states that the issuance of US Treasury securities is not unlimited without undermining the safe asset character of the reserves (Farhi et al. 2011). But the underlying fiscal nature of the modern Triffin dilemma, which would make the reserve system unsustainable in the long run, remains even in a more multipolar world with several reserve currencies. Absent major reforms, future trends in supply and demand for safe (reserve) assets are most likely not that favorable. Supply in safe assets is constrained by the aspiration of most of the richer countries to pursue fiscal consolidation.

As a result of the GFC, about half of the volume of assets perceived as safe prior to the crisis lost this attribute (Caballero et al. 2017). Senior tranches of privately issued assetbacked securities lost their perceived safe-asset status, as the assets underlying these securities consisted of a huge number of illiquid loans, partly non-performing already at the time of issuance. Outstanding bonds of several sovereigns suffered from deteriorating credit quality, following the shouldering of private debt to contain the crisis.

Further, the EU seems unwilling to pool sovereignty and issue euro bonds or sovereign bond-backed securities (SBBS) that could add another layer to the supply of safe assets ${ }^{8}$ (ESRB 2018; Breitenfellner/Schuberth 2017). Demand for reserve assets is fueled by stronger growth in the poorer countries and macroeconomic and financial imbalances that potentially require (reserve) liquidity support in times of stress. The asymmetry in the supply of and demand for safe assets is also compounded by demographic factors that are increasing the demand for safe assets in poorer countries.

In the wake of the GFC, some steps to increase global liquidity, in particular by issuing additional SDR volumes and concluding swap line agreements between central banks, were taken, but rather on an ad hoc basis and without a broader coherent concept.

\section{REFORM PROPOSALS FOR THE GLOBAL MONETARY ORDER}

The partial retreat of the USA from multilateralism since 2016, the still unresolved modern version of the Triffin dilemma as well as the increasing role of the US dollar as a risk factor

7. The original Triffin dilemma referred to the conflict between the growing global demand for the US dollar under the Bretton Woods system and a constant US dollar price of gold, and the mostly fixed amount of gold reserves held by the US government. The USA was faced with a dilemma: it could either reduce demand for US dollar assets by a restrictive monetary policy causing a global recession, or it could stop backing the US dollar with gold reserves, thus making the system of fixed exchange rates unsustainable.

8. It has to be mentioned that the safe-asset character of privately created safe assets with overcollateralization is fairly limited, given the inability of the private sector to insure against systemic risk. 
for emerging market economies and the global economy alike have motivated a broader debate about the perspective reformers take on the global monetary order depending on whether they advocate incremental or more fundamental change (Eichengreen 2016).

\subsection{Incremental reforms}

Incremental reformers envisage a global monetary order that gradually develops into a more multipolar system, with the euro and the renminbi as the second and third pillars. The European Commission (EC) has proposed (well-known) initiatives to strengthen the international role of the euro, also mentioning the need to issue highly liquid euro-denominated safe assets in the form of euro bonds or SBBSs - the conditio sine qua non for achieving substantial progress in strengthening the international role of the euro (EC 2018). China's ambitious internationalization strategy for the renminbi, including financial market liberalization and further liberalization of its capital account as well as the currency's inclusion into the SDR basket in 2016, was temporarily obstructed in 2015-2017 after China experienced episodes of financial turmoil and capital flight.

Setting aside the questions of whether a multipolar world is feasible in the near future and what kind of disruptions are to be expected during the transition period, the issue has to be raised of whether a more multipolar global monetary order makes the world safer. It may do so by solving the Triffin dilemma and increasing the global supply of reserve assets. But it may also induce volatile capital flows between the three key currency issuers, with large fluctuations of exchange and interest rates as a consequence. A reserve currency might rapidly lose its safe-asset status in view of (the perception of) only small changes in fundamentals that may result in self-fulfilling phenomena, similar to the flight-to-safety experience in the euro area in 2010-2012 (Farhi et al. 2011). A fiscal tightening bias could arise, potentially aggravating the Triffin dilemma in turn.

Irrespective of whether the world is unipolar or multipolar, improving the provision of liquidity in times of crisis features prominently in many policy proposals. To partially resolve the Triffin dilemma and address the negative side effects of an overaccumulation of reserves, an expansion of the global financial safety nets (GFSN), for example by enlarging the currently limited network of permanent central-bank swap agreements - complemented by the development of social safety nets in emerging market economies (Farhi et al. 2011) - should reduce demand for reserve assets. After the GFC, the IMF set up new facilities, new regional financial arrangements (RFAs) were created, and bilateral swap agreements were concluded (Mühlich/Fritz 2018). But the current complex, partly decentralized, noninclusive network of arrangements does not ensure that international liquidity will be available to individual countries as appropriate. ${ }^{9}$ One suggestion is to replace a complex network of bilateral swaps with an organized network of established and codified agreements, or to centralize the organization of swap lines at the IMF. This should safeguard swift liquidity provision during systemic crises with a tail-risk nature. ${ }^{10}$ Moral hazard is a concern here. The anticipation of liquidity support may invite financial market participants to set off

9. In 2013 the Bank of Canada, the Bank of England, the Bank of Japan, the European Central Bank, the Federal Reserve System and the Swiss National Bank announced that they had made their swap lines permanent. The lack of democratic legitimacy of excluding other central banks provoked criticism (Pistor 2013).

10. Other possible options include: lending of unused SDRs from member-country savings, market borrowing by the IMF, and expanding the new arrangements to borrow (NAB) when needed (see GFG 2018). 
on new adventures, and engage in carry trades eliciting even more rescues. Addressing these concerns requires close monitoring, correction and (pro-cyclical) sanction mechanisms. This in turn involves governance and policy challenges that are difficult to overcome.

With regard to the volatility of capital flows and the potential disruptive consequences of the global financial cycle, two different types of more modest policy implications are discussed in the literature: First, to increase a country's resilience to pro-cyclicality in capital flows - that is, the influential remedy following the Asian financial crisis of the late $1990 s$ - is still being discussed. Prerequisites are: better fundamentals, deepness of financial markets, ${ }^{11}$ better prudential oversight, more flexible exchange rates, and a substantial stock of foreign-exchange reserves. Two problems arise. First, the list of prerequisites gets longer after each financial crisis, but even more importantly: defensive strategies, such as building up buffers in the form of foreign-exchange reserves, are costly in terms of foregone investment and consumption and may undermine the stability of the global monetary order.

Second, the GFC marked an inflection point that fundamentally influenced economists' thinking of the merits of open capital accounts (Rodrik 2018). After the GFC, the IMF published a new institutional view on capital controls rebranded as capital flow management measures that allowed their temporary use under some circumstances to complement permanent macroprudential policy measures. ${ }^{12}$ The latter are considered the first line of defense, for instance to limit foreign-currency indebtedness. Capital flow management measures have now become a 'legitimate part of the policy toolkit' (Ostry et al. 2010) and are considered particularly effective if capital flows are not intermediated via the banking system. Such measures include both administrative and price-based restrictions on capital flows, that is, bans and limits as well as taxes and reserve requirements. Following the IMF's recommendations, they should be phased out when crises fade and policy space to manage capital flows is restored. Still, the opening-up of the capital account is endorsed when countries reach certain levels of financial and institutional developments.

\subsection{More fundamental reforms}

While incremental reformers aim at strengthening the existing order by mitigating its negative side effects that are often portrayed as an unwelcome deviation from a firstbest view of the world, more fundamental ideas have been put forward that eventually question this first-best perspective. Ideas include a more comprehensive reimposition of capital controls, a new Bretton Woods agreement including cooperation of central banks to stabilize exchange rates, and the replacement of the US dollar as the key reserve currency by a transnational unit, for example, the SDR.

In view of the hypothesis that the nature of the pre-crisis international financial architecture has not been overhauled in a significant manner (Helleiner 2014), many of the incremental reforms have the merit that their implementation may be politically feasible (Eichengreen 2016) but can be considered defensive strategies, discussed amid an incomplete regulation of world finance. Some economists point to the strong global interconnectedness and hence vulnerability to contagion and see private capital flows as prone to short-termism and excessive risk-taking. In this perspective, implementing

11. Interestingly, Eichengreen/Gupta (2015) find that countries with larger and more liquid financial markets were more heavily affected by the taper tantrum in 2013 .

12. For an overview, see IMF (2018b). 
capital controls more permanently may be seen as a way to safeguard financial stability in line with the post-war consensus among economists (Rodrik 2018). In addition, further evidence-based considerations seem to justify a more nuanced view of capital account liberalization. Starting from the observation that the association between capital account convertibility and growth is weak (Rodrik 1998), the GFC has revived literature and research on the costs and benefits of the free movement of capital that go beyond financial stability considerations and concerns with regard to limited room for maneuver of monetary policy. This literature seems to corroborate the use of capital controls in a more permanent manner. Open capital accounts seem to advance a shift in taxation from (mobile) capital to (immobile) labor (see Garretsen/Peeters 2007; Onaran/Boesch 2014; Bretschger/Hettich 2002). The threat to relocate capital may weaken the bargaining power of workers and might explain the decline in labor shares (Furceri et al. 2017; Jaumotte et al. 2013). In general, the asymmetry between capital and labor in terms of their respective mobility put the adjustment burden of idiosyncratic shocks on labor, as argued in Rodrik (1997).

Supporters of this fundamental view are aware that causing the swift disintegration of a financially integrated world may be hazardous and, in the worst case, trigger a tail-risk event. Nonetheless, more research is warranted to study episodes and consequences of opening up the capital account or imposing controls to get a better understanding of the costs and benefits of financial liberalization.

A differentiated strategy of capital flow management measures should not preclude the selective use of foreign private capital to finance investment and catching-up processes. Moreover, such an approach should ideally be complemented by stepped-up public financing arrangements to foster economic development in economies that are characterized by a large net demand for capital imports.

\section{CONCLUSION}

Despite ten years of substantial regulatory reforms, vulnerabilities in the international monetary and financial system have remained a dominant feature of the prevailing global monetary order. These imperfections include: (i) the absence of good substitutes, in the near term, for the US dollar as a reserve asset; (ii) the absence of an adjustment mechanism to address current-account surpluses that are not fundamentally justified; (iii) large and volatile capital flows; and (iv) uncertainty about the availability of and unequal access to international liquidity in times of stress.

Many of the pressing reforms discussed require international cooperation, which, in turn, involves complex governance issues that are not easy to resolve in a world of sovereign nations. This applies, for instance, to the multilateralization of central-bank swap lines, but also, to give another example, to reforms toward a more multipolar world order. Overcoming the political hurdle of issuing euro bonds or SBBS is one of the necessary prerequisites for strengthening the international role of the euro.

However, it is unclear whether a more multipolar currency order makes the world safer. Given the easy exchangeability of key currencies that would then have to be fully convertible, a more multipolar world is likely to feature episodes of high capital flow volatility resulting from (small) changes in the fundamentals of one of the key currency areas. Moreover, ideas have been put forward that aim at more fundamental reforms of the global monetary order. Yet further research is needed to arrive at a thorough assessment of the ideas' feasibility and desirability. 


\section{REFERENCES}

Avdjiev, S., Berger, B., Shin, H.S. (2018a): Gauging procyclicality and financial vulnerability in Asia through the BIS banking and financial statistics, BIS Working Paper No 735.

Avdjiev, S., Bruno, V.G., Koch, C., Shin, H.S. (2018b): The dollar exchange rate as a global risk factor: evidence from investment, BIS Working Paper No 695.

Berglöf, E., Korniyenko, E., Zettelmeyer, J., Plekhanov, A. (2010): Understanding the crisis in emerging Europe, EBRD Working Paper 109.

Bibow, J. (2010): The global crisis and the future of the dollar: toward Bretton Woods III?, Levy Economics Institute Working Paper No 584.

Borio, C., Disyatat, P. (2015): Capital flows and the current account: taking financing (more) seriously, BIS Working Paper No 525.

Breitenfellner, A., Schuberth, H. (2017): Europe needs more than a Capital Markets Union - focus on the integration of euro area sovereign debt markets, in: Vierteljahrshefte zur Wirtschaftsforschung, 85/2, DIW Berlin.

Bretschger, L., Hettich, F. (2002): Globalisation, capital mobility and tax competition: theory and evidence for OECD countries, in: European Journal of Political Economy, 18, 695-716.

Bruno, V., Shin, H.S. (2015): Capital flows and the risk-taking channel of monetary policy, in: Journal of Monetary Economics, 71, 119-132.

Caballero, R.J., Farhi, E., Gourinchas, P.O. (2017): The safe assets shortage conundrum, in: Journal of Economic Perspectives, 31(3), 29-46.

Dooley, M.P., Folkerts-Landau, D., Garber, P. (2003): An essay on the revived Bretton Woods system, NBER Working Paper 9971, The National Bureau of Economic Research.

EC (2018): Towards a stronger international role of the euro: Commission contribution to the European Council and the Euro Summit, December, European Commission.

ECB (2017): Report on financial structures, October, European Central Bank.

ECB (2018a): The international role of the euro, June, European Central Bank.

ECB (2018b): Financial stability review, November, European Central Bank.

Eichengreen, B. (2016): Global monetary order, in: Constancio, V., Hartmann, P. (eds), The Future of the International Monetary and Financial Architecture, European Central Bank.

Eichengreen, B., Gupta, P. (2015): Tapering talk: the impact of expectations of reduced Federal Reserve security purchases on emerging markets, in: Emerging Markets Review, 25, 1-15.

Eller, M., Huber, F., Schuberth, H. (2016): Understanding the drivers of capital flows into the CESEE countries, in: Focus on European Economic Integration, Q2/16, OeNB, 79-104.

Eller, M., Huber, F., Schuberth, H. (2018): How important are global factors for understanding the dynamics of international capital flows?, Working Papers in Economics 2018-2, University of Salzburg.

ESRB (2018): Sovereign bond-backed securities: a feasibility study, January, European Systemic Risk Board.

Farhi, E., Gourinchas, P.O., Rey, H. (2011): Reforming the international monetary system, Centre for Economic Policy Research (CEPR).

Fratzscher, M. (2009): What explains global exchange rate movements during the financial crisis?, in: Journal of International Money and Finance, 28(8), 1390-1407.

FSB (Financial Stability Board) (2015): Principles on loss-absorbing and recapitalisation capacity of G-SIBs in resolution: Total Loss-absorbing Capacity (TLAC) Term Sheet, 9 November.

FSB (Financial Stability Board) (2018): Global shadow banking monitoring report 2017, March, Financial Stability Board.

Furceri, D., Loungani, P., Ostry, J.D. (2017): The aggregate and distributional effects of financial globalization, Unpublished paper, IMF.

Gächter, M., Geiger, M., Glötzl, F., Schuberth, H. (2015): Sectoral deleveraging in Europe and its economic implications, in: Focus on European Economic Integration, Wien: Oesterreichische Nationalbank, 8-23.

Garretsen, H., Peeters, J. (2007): Capital mobility, agglomeration and corporate tax rates: is the race to the bottom for real?, in: CESifo Economic Studies, 53, 263-293. 
GFG (2018): Making the global financial system work for all, Report of the G20 Eminent Persons Group on Global Financial Governance, October.

Gourinchas, P.O., Rey, H. (2007): From world banker to world venture capitalist: US external adjustment and the exorbitant privilege, in: Clarida, R.H. (ed.), G7 Current Account Imbalances: Sustainability and Adjustment, Chicago: University of Chicago Press, 11-66.

Gourinchas, P.O., Rey, H., Govillot, N. (2010): Exorbitant privilege and exorbitant duty, Institute for Monetary and Economic Studies, Bank of Japan, No 10-E-20.

Gourinchas, P.O., Rey, H., Govillot, N. (2017): Exorbitant privilege and exorbitant duty, updated version, URL: http://helenerey.eu/Content/_Documents/duty_23_10_2017.pdf.

Helleiner, E. (2014): The Status Quo Crisis: Global Financial Governance After the 2008 Meltdown, New York: Oxford University Press.

Ilzetzki, E., Carmen, M., Reinhart, R. (2019): Exchange arrangements entering the twenty-first century: which anchor will hold?, in: The Quarterly Journal of Economics, 134(2), 599-646.

IMF (2007): World Economic Outlook: spillovers and cycles in the global economy, April, International Monetary Fund.

IMF (2016): World Economic Outlook: too slow for too long, April, International Monetary Fund.

IMF (2018a): Fiscal Monitor: capitalizing on good times, April, International Monetary Fund.

IMF (2018b): The IMF's institutional view on capital flows in practice, July, International Monetary Fund, Group of Twenty, URL: https://www.imf.org/external/np/g20/pdf/2018/073018. pdf.

IMF (2018c): Global Financial Stability Report: a decade after the global financial crisis - are we safer?, October, International Monetary Fund.

Jaumotte, F., Lall, S., Papageorgiou, C. (2013): Rising income inequality: technology, or trade and financial globalization?, IMF Economic Review, 61(2), 271-309.

Lane, P.R., McQuade, P. (2014): Domestic credit growth and international capital flows, in: The Scandinavian Journal of Economics, 116(1), 218-252.

McCauley, R.N., Bénétrix, A.S., McGuire, P.M., von Peter, G. (2019): Financial deglobalisation in banking?, in: Journal of International Money and Finance, 94, 116-131.

Miranda-Agrippino, S., Rey, H. (2018): US monetary policy and the global financial cycle, NBER Working Paper 21722, The National Bureau of Economic Research.

Mühlich, L., Fritz, B. (2018): Safety for whom? The scattered global financial safety net and the role of regional financial arrangements, in: Open Economies Review, 29(5), 981-1001.

Obstfeld, M. (2013): The international monetary system: living with asymmetry, in: Feenstra, R.C., Taylor, A.M. (eds), Globalization in an Age of Crisis: Multilateral Economic Cooperation in the Twenty-First Century, Chicago: University of Chicago Press, 301-336.

Onaran, Ö., Boesch, V. (2014): The effect of globalization on the distribution of taxes and social expenditures in Europe: do welfare state regimes matter?, in: Environment and Planning A, 46, 373-397.

Ostry, J.D., Ghosh, A.R., Habermeier, K., Chamon, M., Qureshi, M.S., Reinhardt, D. (2010): Capital inflows: the role of controls, in: Revista de Economia Institucional, 12(23), 135-164.

Pistor, K. (2013): Central banking's new club class, Project Syndicate, URL: https://www.projectsyndicate.org/commentary/katharina-pistor-crticizes-the-new-great-divide-in-internationalmonetary-management?barrier=accesspaylog.

Rey, H. (2015): Dilemma not trilemma: the global financial cycle and monetary policy independence, NBER Working Paper 21162, The National Bureau of Economic Research.

Rodrik, D. (1997): Has Globalization Gone Too Far? Washington, DC: Institute for International Economics.

Rodrik, D. (1998): Who needs capital-account convertibility?, in: Kenen, P. (ed.), Essays in International Finance, No 207, Princeton, NJ: Princeton University Press, 55-65.

Rodrik, D. (2018): Populism and the economics of globalization, in: Journal of International Business Policy, 1(1-2), 12-33.

S\&P (2017): U.S. corporate cash reaches $\$ 1.9$ trillion, but rising debt and tax reform pose risk, S\&P Global Ratings, May.

Tooze, A. (2018): Crashed: How a Decade of Financial Crises Changed the World, London: Allen Lane. 
UN (2009): Report of the Commission of Experts of the President of the United Nations General Assembly on Reforms of the International Monetary and Financial System, in: UN Conference on the World Financial and Economic Crisis and its Impact, September, United Nations.

Zhou, X. (2009): The reform of the international monetary system, in: BIS Review 4, 1/2009.

\section{FURTHER READING}

Aizenman, J., Chinn, M.D., Ito, H. (2016): Monetary policy spillovers and the trilemma in the new normal: periphery country sensitivity to core country conditions, in: Journal of International Money and Finance, 68, 298-330.

Farhi, E., Maggiori, M. (2017): A model of the international monetary system, in: The Quarterly Journal of Economics, 133(1), 295-355.

Nurkse, R. (1944): International Currency Experience, Geneva: League of Nations.

Obstfeld, M., Taylor, A.M. (2017): International monetary relations: taking finance seriously, in: Journal of Economic Perspectives, 31(3), 3-28. 